\title{
Immature teratoma in pregnancy
}

\section{Gebelikte ilmmatüir teratom}

\author{
Savas Karakus ${ }^{1}$, Şerife Özlem Genç ${ }^{1}$, Dilay Karademir ${ }^{2}$, Gamze Sönmez ${ }^{1}$, Tahsin Takcı ${ }^{1}$, Buğra \\ Okșaşoğlü ${ }^{1}$, Neșe Yeldirr ${ }^{3}$,Handlan Aker ${ }^{3}$, Ali Yamuk ${ }^{1}$
}

${ }^{1}$ Department of Obstetrics and Gynecology, Cumhuriyet University School of Medicine, Sivas, Turkey

${ }^{2}$ Department of Obstetrics and Gynecology, Sivas State Hospital, Sivas, Turkey

${ }^{3}$ Department of Pathology, Cumhuriyet University School of Medicine, 58140 Sivas, Turkey

Corresponding author: Savaș Karakuș, MD, Department of Obstetrics and Gynecology, Cumhuriyet University School of Medicine, 58140 Sivas,

Turkey

E-mail: karakussavas@yahoo.com

Received/Accepted: April 13,2018/June 29, 2019

Conflict of interest: There is not a conflict of interest.

\section{SUMMARY}

Objective: The most common genital neoplasms in the reproductive period are over tumors. Limitation of radiological examinations done during pregnancy and the concentration of the examination on the fetus, in general, may lead to missed malignancies. The purpose of the study is to discuss the approach to adnexal masses seen in pregnancy.

Case: A 26-year-old woman with a 39-weeks gestation had groin pain. CA125 value: $60 \mathrm{U} / \mathrm{ml}$, CA19-9: 385,5 U/ ml, AFP: 115,1 U/ ml. After birth with $\mathrm{C} / \mathrm{S}$, the right ovary was observed to have a mass of approximately $15 \mathrm{~cm}$. It was followed. The mass was excised, and a frozen section was sent. It was reported to be compatible with the resultant mature teratoma. Upon reporting the final pathologic outcome as immature teratoma grade, 1, post-operative positron emission tomography (PET-CT) imaging and tumor marker screening were planned. PET CT imaging and tumor markers were negative.

Conclusions: $90 \%$ of adnexal masses below $6 \mathrm{~cm}$ are functional cysts between the 16-18th gestational weeks. They usually fall back on their own. Malignancy rate after the operation is 4-6\% in persistent. Except for the presence of acute symptoms or the suspicion of serious malignancy; Surgical intervention should be postponed to the middle of the 2nd trimester (16-18th week). The presence of ovarian cysts with symptomatic ovarian mass presence, over torsion, overcast rupture, acute abdomen, diffuse ascites, rapid growth pattern in pregnancy requires urgent surgical intervention. The frozen section should be sent during the operation if surgical intervention is required. The frozen section determines intraoperative behavior. The number of cross sections during the frozen process is limited. In frozen conditions, as many as three sections can be taken in the laboratory, large-diameter tumors have a higher rate of false diagnosis in the frozen specimen. As in this case, inadequate sampling leads to false negative results in borderline and malign lesions showing focal development. Although this delay in diagnosis causes an adjuvant delay in treatment, ovarian cancer that is detected in pregnancy is usually over-limited (stage 1), so the outcome is not badly affected. Most of them are germ cell tumors and low malignant potential epithelial tumors. It usually shows early stage, low grade, unilaterality. Often, unilateral oophorectomy and surgical staging are sufficient.

Keywords: Adnexial mass, adnexal mass approach in pregnancy, frozen section, teratoma in pregnancy
Savas Karakus

(D) Dilay Karademir

(D) Gamze Sönmez

(iD) Buğra Okşaşoğlu

(D) Neşe Yeldir

(D) Handan Aker

(iD) Ali Yanık

ORCID IDs of the authors:

S.K. 0000-0001-8869-8009

D.K. 0000-0002-9813-4255

G.S. 0000-0001-8546-6958

B.O. 0000-0001-7721-6342

N.Y. 0000-0002-3812-6245

H.A. 0000-0003-3237-9660

A.Y. 0000-0001-9634-2117 
ÖZET

Amaç: Reproduktif çağda en çok görülen genital neoplazmlar over tümörleridir. Gebelikte yapılan radyolojik incelemelerin kısıtlllığı ve incelemenin genelde fetüs üzerine yoğunlaşması malignitelerin atlanmasına neden olabilir. Çalışmanın amacı, gebelikte görülen adneksiyal kitlelere yaklaşımın tartışılmasıııı.

Olgu: 26 yaşında 39 hafta gebeliği olan hastanın kasık ağrısı mevcuttu. CA125 değeri: $60 \mathrm{U} / \mathrm{ml}, \mathrm{CA19}-9$ : 385,5 U/ml, AFP: $115,1 \mathrm{U} / \mathrm{ml}$ idi. Hastaya C/S ile doğum yaptırılmasını takiben gözlemde sağ overde kistik ve solid alanlar içeren yaklaşık $15 \mathrm{~cm}$ olan kitle izlendi. Kitle eksize edilerek frozen kesit gönderildi. Sonuç, matür teratom ile uyumlu olarak bildirildi. Nihai patoloji sonucu immatür teratom grade 1 olarak raporlanması üzerine hastaya postoperatif pozitron emisyon tomografisi (PET-CT) görüntülemesi ve tümör belirteçleri bakılması planlandı. PET CT görüntülemesi ve tümör belirteçleri negatif idi.

Sonuç: 16-18. gebelik haftaları arasında $6 \mathrm{~cm}$ altındaki kompleks olmayan adneksiyel kitlelerin \%90'1 fonksiyonel kistlerdir. Genellikle kendiliğinden gerilerler. Persiste edenlerde operasyon sonrası malignite oranı \%4-6'dır. Akut semptomlar varlığı veya ciddi malignite şüphesi haricinde; cerrahi girişim 2. trimesterin ortasına (16-18.hafta) ertelenmelidir. Gebelikte semptomatik ovaryan kitle varlığı, over torsiyonu, over kist rüptürü, akut batın, yaygın asit varlığı, hızlı büyüme paterni görülen ovaryan kistlerin varlı̆̆ acil cerrahi müdahale gerektirir. Cerrahi müdahale gerekiyorsa ameliyat sırasında frozen gönderilmedir. Frozen kesit intraoperatif davranışı belirler. Frozen işlemi sırasında kesit sayısı sınırlıdır. Frozen şartlarında labaratuvarda en fazla üç kesit alınabildiğinden büyük çaplı tümörlerin frozen tanısında yanlış tanı oranı daha yüksektir. Bu olguda olduğu gibi fokal gelişim gösteren borderline ve malign lezyonlarda da yetersiz örnekleme yanlış negatif sonuç verilmesine yol açmaktadır. Tanıdaki bu gecikme adjuvan tedavide ertelemeye neden olsa da gebelikte saptanan over kanserleri genellikle overlere sinırlı (evre 1) olduğu için sonuçlarda kötü etkilenim olmaz. Bunların çoğu germ hücreli tümörler ve düşük malign potansiyelli epitelyal tümörlerdir. Genellikle; erken evre, düşük grade, unilateralite gösterirler. Çoğu kez tek taraflı ooferektomi ve cerrahi evreleme yeterli olmaktadır.

Anahtar sözcükler: Adneksiyal kitle, frozen kesit, gebelikte adneksiyal kitlelere yaklaşım, gebelikte teratom

\section{INTRODUCTION}

The number of adnexal masses in pregnant women was increased due to the presence of adnexal masses that were not symptomatic and could not be detected by examination using routine ultrasonography in the follow-up pregnant women $^{1,2}$. Ovarian tumors are seen at a frequency varying between $2.4 \%$ and $5.7 \%$ in pregnancy ${ }^{3}$. $70 \%$ of ovarian masses in pregnancy is functional cysts and usually, regress spontaneously ${ }^{4}$. Dermoid cysts form the majority of persistent ${ }^{5}$. Ovarian malignancy can be seen in the frequency of $\quad 0,05-0,07: 1000$ during pregnancy ${ }^{6}$. Approximately $75 \%$ of ovarian germ cell tumors in pregnancy constitute disgerminomas. It is difficult to distinguish ovarian masses as benign and malign in pregnancy, and the surgical decision is not easy when considering fetal and maternal morbidity. The second trimester is the period during which treatment planning. If surgical intervention is performed at the third center under appropriate clinical evaluation, it will reduce fetal and maternal morbidity. Complications such as ovarian torsion, ovarian cyst rupture, or progression due to the possibility of malignancy of the mass, develop in patients when the followup decision is taken is undesirable ${ }^{8}$. Laparotomy should be done on suspicion of malignancy. We aimed to discuss the adnexal mass approach in pregnancy because of a case that detected teratoma in pregnancy.

\section{CASE REPORT}

A 26-year-old woman, who was pregnant 39 weeks according to the first day of her last period ,presenting with groin pain, was admitted to our Clinique. She was diagnosed with an adnexal mass. There was no significant disease in her or her parents medical past. Abdominal ultrasonography revealed a solid mass in her right ovary, which characterized lobule contoured cystic areas. There was minimal fluid around the mass. The patient's laboratory work consisted of CA 125:60 U/ml, CA 19-9:385,5 U/ml, AFP:115,1 U/ml. After informed consent was obtained and the patient underwent $\mathrm{c} / \mathrm{s}$ procedure, which exposed $15 \mathrm{~cm}$ mass with cystic and solid components in her right ovary. The left ovary and the rest internal organs in the abdominal cavity were unaffected. A right unilateral salpingooophorectomy was performed. A sample was taken from the fluid for cytology. And the unilateral salpingo-oophorectomy material was also taken for frozen. Due to a frozen report compatible with mature teratoma, the operation was terminated. Right after the final pathology report confirmed immature teratoma grade 1, positron emission tomography (PET CT) was performed. Results of the PET CT and the tumor markers were found negative. Outpatient follows up was planned . 


\section{DISCUSSION}

Ovarian tumors in pregnancy is a clinical condition which needs to be managed with a multidisciplinary approach. Histopathology, grade, stage of the tumor, the gestational week should be considered during the management of the treatment ${ }^{9}$. Most of the masses are benign, such as functional ovarian cysts, benign cystic teratomas, and serous cystadenomas due to the younger age of patients. Malignant ovarian masses most commonly germ cell and borderline ovarian tumors, are rarely seen and usually low grade $^{10}$. The prognosis of the ovarian cancers in pregnancy has improved because most of the cases can be seen by ultrasonography ${ }^{7}$. Malignant ovarian germ cell tumors are generally unilateral except for some cases with opposite side metastasis. If the metastasis seen intraoperatively, cytoreductive surgery is recommended. Second look laparotomy for germ cell tumors is controversial. If the first operation was insufficient about the stage of the tumor, second look laparotomy or CT has to be considered ${ }^{11}$. In our case, there was no other surgery needed because the frozen report was benign.Germ cell tumors are extremely chemosensitive. Patients with stage 1 a grade 1 tumor were shown perfect prognosis. The postoperative observation was recommended without any adjuvant treatment. If extra-ovarian metastasis is present, chemotherapy with BEP protocol is suggested ${ }^{12,13}$.For the young patient's fertility, it is recommended to perform USO, and intraoperative careful examine on abdominal cavity during the laparotomy ${ }^{14}$.

As a result, both fetus and adnexal structures should be examined in ultrasonography; so ovarian malignancies accompanying pregnancy can be diagnosed at an early stage.

\section{REFERENCES}

1. Nick AM, Schmeler K. Adnexal masses in pregnancy. Perinatology 2010; 1: 13-9.

2. Roberts CL, Weston MJ, Bilateral massive ovarian edema: a case report. Ultrasound Obstet Gynecol 1998;11:65-7.

3. Studzinski, Filipczak A, Branicka D. Coexistence of ovarian epithelial tumor of borderline malignancy with pregnancy: a case report. Ginekol Pol. 1999;70(2):101-4

4. Giuntoli RL 2nd, Vang RS, Bristow RE. Evaluation and management of adnexal masses during pregnancy. Clin Obstet Gynecol 2006; 49: 492 .
5. Schmeler KM, Mayo-Smith WW, Peipert JF, et al. Adnexal masses in pregnancy: surgery compared with observation. Obstet Gynecol 2005; 105:1098.

6. Sivanesaratnam V. Gynaecological malignancies in pregnancy. Rev Gynaecol Pract 2004; 4(3): 162-8.

7. Bakri YN, Ezzat A. Malignant germ cell tumors of the ovary. Pregnancy considerations. Eur J Obstet Gynecol Reprod Biol 2000; 90:87.

8. Dudkiewicz J, Kowalski T, Grzonka D, Czarnecki M. Ovarian tumors in pregnancy. Ginekol Pol. 2002;73(4):342-5

9. Mendivil AA, Brown III JV, Abaid LN, Rettenmaier MA, Micha JP, Wabe MA, et al. Robotic-assisted surgery for the treatment of pelvic masses in pregnant patients: A series of four cases and literature review. Journal of Robotic Surgery 2013; 7: 333-337.

10.Leiserowitz GS. Managing ovarian masses during pregnancy. Obstet Gynecol Surv. 2006;61(7):463-70.

11.Gershenson DM, del Junco G, Silva EG, Copeland LJ, Wharton JT, Rutledge FN. Immature teratoma of the ovary. Obstet Gynecol 1986; 68: 624-9.

12.Mourali M, Ben Haj Hassine A, El Fekih C, EssoussiChikhaoui J, Binous N, Ben Zineb N, et al. Immature teratoma of the ovary and pregnancy. (In French). Tunis Med 2010; 88: 507-12.

13.Mangili G, Scarfone G, Gadducci A, Sigismondi C, Ferrandina G, Scibilia G, et al. Is adjuvant chemotherapy indicated in stage I pure immature ovarian teratoma (IT)? A multicentre Italian trial in ovarian cancer (MITO-9). Gynecol Oncol 2010; 119: 48-52.

14.Pectasides D, Pectasides E, Kassanos D. Germ cell tumors of the ovary. Cancer Treat Rev 2008; 34: 427-41 